\title{
Investigation of the Writing Anxiety of Syrian Refugees Learning Turkish as a Foreign Language in Turkey
}

\author{
Sedat Erol ${ }^{1}$ \\ ${ }^{1}$ Department of Turkish and Social Sciences Education, Faculty of Education, Adiyaman University, Turkey \\ Correspondence: Sedat Erol, Department of Turkish and Social Sciences Education, Faculty of Education, \\ Adıyaman University, Turkey. E-mail: sedaterol02@hotmail.com
}

\author{
Received: February 12, 2021 \\ Accepted: March 15, 2021 \\ Online Published: May 7, 2021 \\ doi:10.5539/ies.v14n6p23 \\ URL: https://doi.org/10.5539/ies.v14n6p23
}

\begin{abstract}
The aim of this study was to determine and investigate the writing anxiety of Syrian refugees learning Turkish as a foreign language in Turkey according to different variables. The study group of the research, in which survey model was used, consisted of 214 Syrian refugees chosen via purposive sampling method and who learn Turkish as a foreign language in Turkey. "Writing Anxiety Scale for Learners of Turkish as a Foreign Language" was used as data gathering tool in the research. In the analysis process, firstly normality test was conducted and it was determined that it indicated normal distribution. Accordingly, t-test was used in pair independent samples, and one-way ANOVA test was used in multi-group comparisons. As a result of the research, it was determined that writing anxiety level of the Syrian refugees learning Turkish as a foreign language (L2) in Turkey, was at medium level and also their writing anxiety was caused by environmental/social factors rather than internal/mental factors. In addition, when the situation was evaluated according to their language levels, it was determined that students at B2 level had the highest level of anxiety; and that using Turkish in social media reduces the action-oriented anxiety of the students. When the participants' writing anxiety was investigated according to gender, age, and time spent in Turkey it was found that a significant difference was not indicated.
\end{abstract}

Keywords: foreign language, Turkish, refugee, writing, anxiety

\section{Introduction}

Writing, which is defined as expressing what an individual hears, sees, thinks, designs and experiences processing mentally with symbols according to certain rules, is the skill that requires most practice among language skills (Sever, 2004; Özbay, 2006; Göçer, 2007; Karatay \& Aksu, 2017). For this reason, it is also known as the skill which is acquired at the most difficult and latest way. Writing skill, which is built on other skills, emerges and develops depending on the systematic realization of cognitively complex operations in a certain order (Ülper \& Çeliktürk Sezgin, 2019). In writing process, firstly a meaning, which is to be conveyed, appears in human mind. After selection and coding of linguistic equivalents of the meaning, the feeling/thought to be conveyed becomes visible as a text. In this respect, writing is a production process (Karadağ \& Maden, 2014). This is one of the fundamental reasons why writing skill is emphasized in constructive language approach. As in writing process, while information is structured in the mind, operations such as examining, reviewing, questioning, associating, checking information are performed. The realization of these mental processes also provides the structure of the mind to be organized (Güneş, 2014).

While writing, elements that control emotions are eliminated and individuals are provided to confront their own emotions and recognize themselves (Aric1 \& Ungan, 2015). In this process, besides features such as communicating with a reader, expressing ideas without the pressure of face to face communication, processes such as discovering a subject and recording experiences are performed (Ann, 1983). In this context, it can be stated that efficiency of writing process is related to person's background, perception of the outside world, and evaluation of acquisitions in inner world (Bağc1, 2011). In other words, writing is a cognitive, emotional and cultural process (Zhang, 2011; Günaydın \& Arıc1, 2020).

Writing is not only an emotional but a cognitive activity as well. Individual thinks and feels while writing (Cheng, 2002). In this process, as in other language skills, it is known that various emotional states affect success in a positive or negative way. One of these emotional states is anxiety (İşeri \& Ünal, 2012). Anxiety, which is defined as "the feeling of sadness, worry, distress and tension of unknown origin generally because of the idea as if 
something bad is going to happen" (TDK, 2017), especially appears in the process of writing feelings and thoughts, affects the individual's perception of writing and leads to a negative attitude towards writing (Zorbaz, 2011).

Writing anxiety, which represents the distress and fear that occurs in individual during the process of transferring via writing, is related to avoiding individuals' desire to write or tendency to writing (Faigley, Daly, \& Witte, 1981; Tiryaki, 2012). One of the main causes of writing anxiety is that individuals feel weak and incompetent in terms of writing skills. This situation, which is expressed as "negative self-concept" in literature, expresses the tendency to avoid writing especially by individuals who have poor writing skills, and consider writing as difficult and challenging to overcome (Zorbaz, 2011). Writing anxiety, which affects individuals' written expression skills and causes them to become distant from writing, is in a way a reaction developed against writing. This reaction against writing not only appears in situations where writing is compulsory as sadness, anger, and fear in emotional contexts but it can appear in the form of various severe physical problems as well (Özbay \& Zorbaz, 2011).

Writing anxiety can affect the learner at all levels of writing skill and cause the learner to avoid writing (Corbett-Whittier, 2004). According to Daly (1985), positive attitude on writing depends on development and continuity in the writing process. Not being able to develop writing skills in teaching process and lack of continuity in writing activities lead to the emergence of negative attitudes towards writing. This negative attitude towards writing in the individual affects writing process over time and creates writing anxiety in the individual (cited, Zorbaz, 2011). In some researches related to the subject, it was found that students with high anxiety have less command of written expressions due to the lack of writing skills and better learners experience less anxiety compared to weak ones. (Abu-Ghararah, 1999; Bağ, 2013; Göçer, 2014; Yan \& Horwitz, 2008; Daud et al., 2005; Martinez et al., 2011; Faigley et al., 1981; Shang, 2013). In this respect, it can be stated that anxiety is an important factor in the development of writing skills in a foreign language (Akpur, 2005; Batumlu, 2006; Çelebi, 2009; Dalkılıç, 2001; Gülsün, 1997; Karakaya \& Ülper, 2011).

Writing anxiety in the second language, which is closely related to the beliefs, attitudes and perceptions that an individual develops towards the language learned, is an anxiety peculiar to language skill (Cheng et al.1999; Horwitz, Horwitz, \& Cope, 1986). It can be stated that in the process of foreign language learning, which requires more motivation and effort compared to first language learning, learner sometimes experiences distress/fear of not being able to achieve the desired acquisitions and being unsuccessful. It is seen that this problem is encountered especially in the development of writing skill which is built on other skills. Because writing, which requires high level cognitive abilities, is a production process that includes emotional and cultural elements. The learners, who have difficulties in this process, find their goals more inaccessible, experience the lack of self-confidence and builds psychological walls. As a result of this situation, writing anxiety in foreign language emerges.

When the literature is examined, it is seen that many studies were conducted regarding writing anxiety in foreign language teaching (Horwitz et al., 1986; Cheng et al., 1999; Cheng, 2002; Cheng, 2004; Daud et al., 2005; Lin \& Ho, 2009; Öztürk \& Çecen, 2007; Zhang, 2011; Choi, 2013; Shang, 2013; Rezaei \& Jafari, 2014; Ho, 2016; Liu \& Ni, 2015; Kırmızı \& Kırmız1, 2015; Jebreil et al., 2015; Kassem, 2017; Ekmekçi, 2018; Jawas, 2019). However, considering teaching Turkish as a foreign language, it is seen that there are very few studies on writing anxiety. Aytan and Tunçel (2015), Maden, Dinçel, and Maden (2015), Şen and Boylu (2017), and Tayşi (2018) contributed to literature by developing a writing anxiety scale regarding learners of Turkish as a foreign language. Studying the writing anxiety of learners of Turkish as a foreign language at the University of Jordan, İscan (2015) found that somatic (physical) and social anxiety levels of the students were high and their cognitive anxiety levels were at low level. Conducting their self-developed writing anxiety scale to the study group, which mostly consisted of Turkish students, Maden, Dinçel, and Maden (2015), found that students mostly feel anxious while writing in Turkish, and their anxiety levels differ depending on factors such as nationality, alphabet difference, and reading habits. Akbulut (2016), who researched about learning Turkish as a foreign language in Turkey by learners from other nationalities, found that learners whose first language was Arabic had writing anxiety at high level. Studying the effect of peer assessment application on writing anxiety in teaching Turkish as a foreign language, Karateke-Bayat (2018) found that peer assessment application conducted in writing classes reduced students' writing anxiety. Taşdemir (2017), who aimed to examine the effect of special writing on writing anxiety and writing tendency in teaching Turkish as a foreign language, found that there was a significant difference in writing anxiety levels of students before and after special writing practices. Barış and Şen (2019), who researched writing anxiety of foreign students studying university in Turkey, found that environment oriented anxiety of the students was higher than their action oriented anxiety. Balc1 (2020), who researched the writing anxiety of the students coming from Asia, Europe and Africa and learning Turkish as a foreign language in Turkey, found that students' writing anxiety differ according to their country, nationality, and first language. Unlike other studies in this study it was aimed to 
determine and investigate the writing anxiety of Syrian refugees studying in Turkey according to different variables.

\subsection{Purpose of the Research}

The purpose of this research is to determine and investigate the writing anxiety of Syrian refugees learning Turkish as a foreign language (L2) in Turkey according to different variables. For this purpose, answers were searched for the following questions:

For Syrian refugees learning Turkish as a foreign language in Turkey;

1) What is the level of writing anxiety and at which sub-dimensions do they increase?

2) Does the writing anxiety indicate significant difference according to gender variable?

3) Does the writing anxiety indicate significant difference according to age variable?

4) Does the writing anxiety indicate significant difference according to language levels?

5) Does the writing anxiety indicate significant difference according to the time spent in Turkey?

6) Does the writing anxiety indicate significant difference according to the status of using Turkish language in social media?

\section{Method}

\subsection{Research Model}

Survey model was used in this research, which aimed to determine and investigate writing anxiety of Syrian refugees learning Turkish as a foreign language (L2) in Turkey according to different variables. In this model the main purpose is to determine a past or present situation as it exists. For this purpose, current objects are described and expressed quantitatively (Ekiz, 2017; Köse, 2017; Sönmez \& Alacapınar, 2013).

\subsection{Study Group of the Research}

The study group, who were chosen via purposive sampling method, consists of 214 Syrian refugees learning Turkish as a foreign language in Turkey. The demographic features of the students participating in the study are indicated in Table 1.

Table 1. Demographic features regarding the study group

\begin{tabular}{lccc}
\hline \multirow{2}{*}{ Gender } & & $\mathrm{f}$ & $\%$ \\
\hline & Female & 112 & 52.3 \\
& Male & 102 & 47.7 \\
\hline \multirow{2}{*}{ Age } & $15-18$ & 21 & 9.8 \\
& $18-21$ & 79 & 36.9 \\
& $21-24$ & 69 & 32.2 \\
& $24-27$ & 21 & 9.8 \\
Language level & $27-30$ & 13 & 6.1 \\
& 30 and older & 11 & 5.2 \\
\hline & B1 & 41 & 19.2 \\
Time spent in Turkey & B2 & 55 & 25.7 \\
& C1 & 118 & 55.1 \\
\hline & $1-3$ & 26 & 12.1 \\
The status of using Turkish in social media & $3-6$ & 92 & 43.0 \\
& $6-9$ & 86 & 40.2 \\
Total & 9 and older & 10 & 4.7 \\
\hline
\end{tabular}

According to Table $1,52.3 \%$ of the students participating in the research are female and $47.7 \%$ are male. $9.8 \%$ of the participants were $15-18$ years old, $36.9 \%$ were $18-21,32.2 \%$ were $21-24,9.8 \%$ were $24-27,6.1 \%$ were $27-30$, 
$5.2 \%$ were 30 and older. According to the language level, 19.2\% of the students were at B1 level, $25.7 \%$ of them were at $\mathrm{B} 2$ level and $55.1 \%$ of them were at $\mathrm{C} 1$ level. According to the time spent in Turkey $12.1 \%$ of the students were in Turkey for $1-3$ years, $43 \%$ for $3-6,40.2 \%$ for $6-9$ years and $4.7 \%$ were 9 years and more. $14 \%$ of students never, $58 \%$ of them sometimes and $28 \%$ of them always use Turkish in social media.

\subsection{Data Gathering Tools}

"Writing Anxiety Scale for Learners of Turkish as a Foreign Language”, which was developed by Şen and Boylu (2017), was used as a data gathering tool in the research where data was gathered via Google Forms. The scale, in which 13 items ranked in 5-point Likert type, consists of two sub-dimensions; action oriented anxiety and environment oriented anxiety. As a result of the analyses the researchers, who developed the scale, found the reliability coefficient of the scale as .84. In this study, the reliability coefficient of the scale was calculated as .79 .

\subsection{Analysis of the Data}

The data obtained from the "Writing Anxiety Scale for Learners of Turkish as a Foreign Language" was analyzed with SPSS 23 package program in the research. Firstly, whether the data indicated a normal distribution or not was checked in order to determine the tests to be used in the analysis of the data. Accordingly, the skewness, kurtosis and Shapiro-Wilk test significance values of total scores obtained from the scales were examined. The values accessed regarding this process are given in Table 2 .

Table 2. Normality values regarding the scale and sub-dimensions

\begin{tabular}{lccc}
\hline Groups & Skewness & Kurtosis & $\mathrm{p}$ \\
\hline Action oriented anxiety & -.707 & -.015 & .000 \\
Environment oriented anxiety & -.087 & -.574 & .022 \\
Writing anxiety (total score) & -.331 & -.391 & .009 \\
\hline
\end{tabular}

When Table 2 is examined, considering the values of skewness and kurtosis it is seen that the values of the anxiety skewness and kurtosis change between +1 and -1 in both groups, and that the values of the Shapiro-Wilk test indicate a normal distribution although the values are significant (Kim \& Ehrmann, 2013). As in the subtests of the scale, it was found that the Shapiro-Wilk test result of the total score of the scale is also significant, however, since the skewness and kurtosis values indicate a normal distribution, parametric tests could be used in all operations (Can, 2014). While $\mathrm{t}$ test was used in independent samples in paired groups, one way ANOVA test was used in multi group comparisons.

\section{Findings}

\subsection{Findings Regarding the First Question of the Research}

Findings regarding the question "What is the level of writing anxiety of Syrian refugees learning Turkish as a foreign language (L2) in Turkey and at which sub-dimensions do they increase?" are included in Table 3.

Table 3. Descriptive analysis results regarding the writing anxiety of the participants

\begin{tabular}{ccccc}
\hline & $\mathrm{N}$ & Average & Mod & Median \\
\hline Action oriented anxiety & 214 & 2.51 & 3 & 2.29 \\
Environment oriented anxiety & 214 & 2.90 & 3 & 2.83 \\
Writing anxiety (total score) & 214 & 2.69 & 2 & 2.69 \\
\hline
\end{tabular}

According to Table 3 writing anxiety of Syrian refugees learning Turkish as a foreign language in Turkey were at medium level considering the general of the scale (2.69) and action oriented anxiety (2.51) sub-dimension, also it was slightly above the medium level in environment oriented anxiety sub-dimension. When the two sub-dimensions of the scale were compared, it was seen that the average of action oriented anxiety (2.51) was lower than the average of environment oriented anxiety (2.90). In this context, it can be stated that the writing anxiety of the participants was caused by environmental/social factors rather than internal $/$ mental factors.

\subsection{Findings Regarding the Second Question of the Research}

Findings regarding the question "Does the writing anxiety of Syrian refugees learning Turkish as a foreign language (L2) in Turkey indicate significant difference according to gender variable?" are included in Table 4. 
Table 4. T-test results regarding the analysis of writing anxiety of the participants according to gender

\begin{tabular}{|c|c|c|c|c|c|c|c|}
\hline & Gender & $\mathrm{N}$ & $\mathrm{X}$ & $\mathrm{S}$ & $\mathrm{sd}$ & $\mathrm{t}$ & $\mathrm{p}$ \\
\hline \multirow{2}{*}{ Action oriented anxiety } & Female & 112 & 2.42 & .82 & \multirow{2}{*}{212} & \multirow{2}{*}{1.59} & \multirow{2}{*}{.190} \\
\hline & Male & 102 & 2.62 & .92 & & & \\
\hline \multirow{2}{*}{ Environment oriented anxiety } & Female & 112 & 2.90 & .72 & \multirow{2}{*}{212} & \multirow{2}{*}{0.62} & \multirow{2}{*}{.602} \\
\hline & Male & 102 & 2.90 & .70 & & & \\
\hline \multirow{2}{*}{ Writing anxiety (total score) } & Female & 112 & 2.64 & .50 & \multirow{2}{*}{212} & \multirow{2}{*}{1.49} & \multirow{2}{*}{.823} \\
\hline & Male & 102 & 2.74 & .47 & & & \\
\hline
\end{tabular}

According to Table 4 writing anxiety of Syrian refugees learning Turkish as a foreign language in Turkey (total score) does not indicate a significant difference according to gender $[\mathrm{t}(212)=1: 49 ; \mathrm{p}>.50]$. The sub-dimensions of the scale; action oriented anxiety $[\mathrm{t}(212)=1.59 ; \mathrm{p}>.50]$ and environment oriented anxiety $[\mathrm{t}(212)=0.62$; $\mathrm{p}>.50$ ], were examined it was seen that there was no significant difference according to gender variable.

\subsection{Findings Regarding the Third Question of the Research}

Findings regarding the question "Does the writing anxiety of Syrian refugees learning Turkish as a foreign language (L2) in Turkey indicate significant difference according to age?" are included in Table 5.

Table 5. ANOVA test results regarding the analysis of writing anxiety of the participants according to age

\begin{tabular}{ccccccc}
\hline & & Sum of Square & $\mathrm{df}$ & Mean Square & $\mathrm{F}$ & $\mathrm{p}$ \\
\hline \multirow{4}{*}{ Action oriented anxiety } & Between groups & 3.893 & 5 & .779 & & \\
& Within groups & 159.460 & 208 & .767 & 1.016 & .409 \\
& Total & 163.353 & 213 & & & \\
\hline \multirow{5}{*}{ Environment oriented anxiety } & Between groups & 1.318 & 5 & .264 & & \\
& Within groups & 107.011 & 208 & .514 & .512 & .767 \\
& Total & 108.328 & 213 & & & \\
\hline \multirow{5}{*}{ Writing anxiety (total score) } & Between groups & 1.036 & 5 & .207 & & \\
& Within groups & 50.283 & 208 & .242 & .857 & .511 \\
& Total & 51.319 & 213 & & & \\
\hline
\end{tabular}

According to Table 5 writing anxiety of Syrian refugees learning Turkish as a foreign language in Turkey (total score) does not indicate a significant difference according to age variable $(\mathrm{p}=.511>.50)$. When the sub-dimensions of the scale; action oriented anxiety $(\mathrm{p}=.409>.50)$ and environment oriented anxiety $(\mathrm{p}$ $=.767>.50$ ) were examined, it was seen that there was no significant difference according to age variable.

\subsection{Findings Regarding the Fourth Question of the Research}

Findings regarding the question "Does the writing anxiety of Syrian refugees learning Turkish as a foreign language (L2) in Turkey indicate significant difference according to language levels?" are included in Table 6.

Table 6. ANOVA test results regarding the analysis of participants' writing anxiety according to language level

\begin{tabular}{ccccccc}
\hline & & Sum of Squares & df & Mean Square & F & p \\
\hline \multirow{4}{*}{ Action oriented anxiety } & Between groups & 5.981 & 2 & 2.991 & & \\
& Within groups & 157.372 & 211 & .746 & 4.010 & $.020^{*}$ \\
& Total & 163.353 & 213 & & & \\
\hline \multirow{4}{*}{ Environment oriented anxiety } & Between groups & 1.245 & 2 & .622 & & \\
& Within groups & 107.083 & 211 & .508 & 1.226 & .295 \\
& Total & 108.328 & 213 & & & \\
\hline \multirow{3}{*}{ Writing anxiety (total score) } & Between groups & 1.484 & 2 & .742 & & \\
& Within groups & 49.835 & 211 & .236 & 3.142 & $.045^{*}$ \\
& Total & 51.319 & 213 & & & \\
\hline
\end{tabular}

$* \mathrm{p}<.50$. 
According to Table 6 writing anxiety of Syrian refugees learning Turkish as a foreign language in Turkey (total score) indicated significant differences according to language level $(\mathrm{F}(2-211)=3.142, \mathrm{p}<.50)$. In addition, it was seen that there was a statistically significant difference in the action oriented anxiety sub-dimension (F (2-211) = $4.010 ; \mathrm{p}<.50)$. On the other hand, no significant difference was found according to language levels of participants in environmental anxiety sub dimension $(\mathrm{F}(2-211)=1.226 ; \mathrm{p}>.50)$. LSD test, one of the multiple comparison tests, was conducted to determine which groups caused significant differences. The results of this test are included in Table 7.

Table 7. Post Hoc test results regarding the analysis of the participants' writing anxiety according to language level

\begin{tabular}{ccccccc}
\hline & Level & Levels & Average Difference & Sh & $\mathrm{p}$ \\
\hline \multirow{3}{*}{ Action oriented anxiety } & & $\mathrm{B} 1$ & $\mathrm{~B} 2$ & -.266 & .178 & .330 \\
& & $\mathrm{C} 1$ & .133 & .157 & .697 \\
& $\mathrm{~B} 2$ & $\mathrm{~B} 1$ & .266 & .178 & .330 \\
& & $\mathrm{C} 1$ & $.399^{*}$ & .141 & .020 \\
\hline \multirow{2}{*}{ Writing anxiety (total score) } & \multirow{2}{*}{$\mathrm{B} 1$} & $\mathrm{~B} 2$ & $-.206^{*}$ & .100 & .042 \\
& $\mathrm{~B} 2$ & $\mathrm{C} 1$ & -.021 & .088 & .809 \\
& & $\mathrm{~B} 1$ & $.206^{*}$ & .100 & .042 \\
& & & & $.184^{*}$ & .079 & .021 \\
\hline
\end{tabular}

$* \mathrm{p}<.50$.

When Table 7 was examined, it was seen that significant difference between levels in the action oriented anxiety sub-dimension resulted from $\mathrm{B} 2$ and $\mathrm{C} 1$ levels, and anxiety of the students at B2 level was higher than the students at $\mathrm{C} 1$ level. Considering the total score of writing anxiety, it was understood that there was a significant difference among B1-B2, B2-C1 levels. When these differences were examined, it was seen that the writing anxiety of students at B2 level was higher than B1 level and C1 level. In this case, it can be stated that students at B2 level had the highest level of anxiety.

\subsection{Findings Regarding the Fifth Question of the Research}

Findings regarding the question "Does the writing anxiety of Syrian refugees learning Turkish as a foreign language (L2) in Turkey indicate significant difference according to the time spent in Turkey?" are included in Table 8 .

Table 8. ANOVA test results regarding the analysis of the participants' writing anxiety according to time spent in Turkey

\begin{tabular}{ccccccc}
\hline & & Sum of Squares & df & Mean square & F & p \\
\hline \multirow{4}{*}{ Action oriented anxiety } & Between Groups & 3.875 & 3 & 1.292 & & \\
& Within Groups & 159.478 & 210 & .759 & 1.701 & .184 \\
& Total & 163.353 & 213 & & & \\
\hline \multirow{4}{*}{ Environment oriented anxiety } & Between Groups & 2.460 & 3 & .820 & & \\
& Within Groups & 105.868 & 210 & .504 & .1626 & .613 \\
& Total & 108.328 & 213 & & & \\
\hline \multirow{3}{*}{ Writing anxiety (total score) } & Between Groups & .439 & 3 & .242 & & \\
& Within Groups & 50.881 & 210 & 1.292 & .1701 & .168 \\
& Total & 51.319 & 213 & & & \\
\hline
\end{tabular}

According to Table 8 writing anxiety of Syrian refugees learning Turkish as a foreign language in Turkey (total score) indicate no significant difference according to time spent in Turkey $(\mathrm{p}=.168>.050)$. When the dimensions of the scale, action oriented anxiety $(\mathrm{p}=.184>.50)$ and environment oriented anxiety $(\mathrm{p}=.613>.50)$ were examined it was seen that there was no significant difference according to time spent in Turkey.

\subsection{Findings Regarding the Sixth Question of the Research}

Findings regarding the question "Does the writing anxiety of Syrian refugees learning Turkish as a foreign language (L2) in Turkey indicate significant difference according to the situation of using Turkish language in 
social media?" are included in Table 9.

Table 9. ANOVA test results regarding the analysis of participants' writing anxiety according to using Turkish in social media

\begin{tabular}{ccccccc}
\hline & & Sum of Squares & df & Mean Square & F & p \\
\hline \multirow{4}{*}{ Action oriented anxiety } & Between groups & 8.701 & 2 & 4.350 & & \\
& Within groups & 154.653 & 211 & .733 & 5.935 & $.003^{*}$ \\
& Total & 163.353 & 213 & & & \\
\hline \multirow{5}{*}{ Environment oriented anxiety } & Between groups & 1.232 & 2 & .616 & & \\
& Within groups & 107.096 & 211 & .508 & 1.214 & .299 \\
& Total & 108.328 & 213 & & & \\
\hline \multirow{5}{*}{ Writing anxiety (total score) } & Between groups & 1.196 & 2 & .598 & & \\
& Within groups & 50.123 & 211 & .238 & 2.518 & .083 \\
& Total & 51.319 & 213 & & & \\
\hline
\end{tabular}

$* \mathrm{p}<.50$.

When Table 9 is examined it is seen that writing anxiety of Syrian refugees, learning Turkish as a foreign language in Turkey does not indicate a significant difference according to using Turkish social media in the general of the scale $[\mathrm{F}(2-211)=2.518 ; \mathrm{p}>.50]$ and in environment oriented anxiety sub-dimension $[\mathrm{F}(2-211)=1.214 ; \mathrm{p}>.50]$. It was found that there was a significant difference in the action oriented anxiety sub-dimension $(\mathrm{F}=5.935 ; \mathrm{p}$ $<.50$ ). LSD test, which is one of the multiple comparison tests, was used to determine which categories caused significant differences. The results of the analysis are included in table 10.

Table 10. Post Hoc Test results regarding the analysis of the participants' action oriented anxiety according to using Turkish on social media

\begin{tabular}{|c|c|c|c|c|c|}
\hline & Status of using & Status of using & Mean Difference & $\mathrm{Sh}$ & $\mathrm{p}$ \\
\hline \multirow{4}{*}{ Action oriented anxiety } & \multirow{2}{*}{ Never } & Sometimes & $.435^{*}$ & .174 & .013 \\
\hline & & Always & $.660^{*}$ & .191 & .001 \\
\hline & \multirow{2}{*}{ Sometimes } & Never & $-.435^{*}$ & .174 & .013 \\
\hline & & Always & .225 & .135 & .097 \\
\hline
\end{tabular}

${ }^{*} \mathrm{p}<.50$.

When Table 10 is examined, it is seen that the significant difference between action oriented anxieties in terms of using Turkish in social media results from the difference between the never-sometimes, never-always categories. Considering the mean differences, it is seen that learners who never use Turkish on social media hah higher action oriented anxiety than the ones who sometimes or always use it. In this context, it can be stated that using Turkish in social media reduces students' inner/mental anxiety.

\section{Conclusion, Discussion and Recommendations}

Writing is a cognitive, emotional and cultural process. In this respect, in developing writing skills in a foreign language (L2), the existence of not only cognitive processes, cultural characteristics but also emotional processes such as anxiety and attitudes should be taken into account, and their causes and effects should be noticed (Zhang, 2011). In this context, research's purpose was to determine and examine writing anxiety of Syrian refugees learning Turkish as a foreign language in Turkey according to different variables. 214 refugees whose first language was Arabic were accessed to gather data. As a result of the analysis of obtained data it was found that writing anxiety of Syrian refugees learning Turkish as a foreign language in Turkey was at medium level considering the general of the scale and action oriented anxiety sub-dimension and also it was slightly above medium level considering environment oriented anxiety sub-dimension. When the two sub-dimensions of the scale were compared, it was determined that the average of action oriented writing anxiety (2.51) was lower than the average of environment oriented writing anxiety (2.90). In this context, it can be stated that the participants had a medium level of writing anxiety and their writing anxiety was caused by environmental/social factors rather than internal/mental factors. When related literature was examined, in their study in which mostly Turkish students participated Maden, Dinçel, and Maden (2015), found that Turkish learners in Turkey mostly feel anxious while 
writing. In addition, it was determined that foreign students' anxiety to write in Turkish considering the alphabets they use in their countries differs in favor of those who use the Latin alphabet, and those who use the Arabic alphabet had the highest anxiety. Studying the writing anxiety of Turkish learners as a foreign language at the University of Jordan, İşcan (2015) found that somatic (physical) and social anxiety levels of the students, whose first language was Arabic, were high and their cognitive anxiety levels were low. Doing research on writing anxiety and attitudes of foreign students learning Turkish as a foreign language in Turkey, Akbulut (2016), found that the writing anxiety of learners, whose first language was Arabic, was higher than those who had other first languages. Researching the writing anxiety of foreign students, who study university in Turkey, Barış and Şen (2019) found that environment oriented anxiety of the students was higher than action oriented anxiety. In this context, it can be stated that there are results not only related to the results of this research in related literature but different results were reached as well.

When the writing anxiety of Syrian refugees learning Turkish as a foreign language was examined according to language level, it was found that B2 students had highest level of anxiety. In the related literature, in their studies Akbulut (2016) and Balc1 (2020) found that the writing anxiety of the learners of Turkish as a foreign language in Turkey does not indicate a significant difference according to language level. In this respect, the result obtained in the research was different from the related literature.

In the study, it was found that the writing anxiety of refugees learning Turkish as a foreign language does not indicate a significant difference either in the general of the scale or sub-dimensions according to gender, age and time spent in Turkey. In the related literature, Maden (2015), Akbulut (2016), Barış and Şen (2019) and Balcı (2020) found that gender variable is not an effective factor on writing anxiety. Taşdemir (2017), on the other hand, found that the writing anxiety of male participants was higher than female participants and male participants had higher prejudices than female participants. Considering the variables of age and time spent in Turkey, Balc1 (2020), who researched the writing anxiety of the students coming from Asia, Europe and Africa and learn Turkish as a foreign language in Turkey, found that these variables were not effective on the writing anxiety of the students. In this context, it can be stated that the result of this research is similar to other studies in the literature regarding the analysis of writing anxiety according to gender, age and time spent in Turkey.

The research included an important variable that was not encountered in the related literature, and the effect of participants' using Turkish in social media on their writing anxiety was examined. As a result of the research, it was determined that using Turkish in social media reduces the action oriented (internal $/$ mental) anxiety of the students. In this respect, it can be stated that social media, which is one of the effective elements of digital age, also affects foreign language teaching process.

Recommendations based on the results obtained in the research:

- Writing clubs can be established in order to reduce the environmental-oriented writing anxiety of refugees.

- Socio-cultural writing activities can be organized for refugees.

- Social media can be used as an effective tool in teaching Turkish as a foreign language to refugees.

\section{References}

Abu-Ghararah, A. H. (1999). Learning anxiety and English language achievement of male and female students of university and secondary stages in Al-Madinah Al-Munawwarah: A comparative research study. King Abdulaziz University Journal, 12, 3-29. https://doi.org/10.4197/edu.12-1.2

Akbulut, S. (2016). Yabancı dil olarak Türkçe ögrenenlerin yazmaya yönelik tutum ve kaygıları (Yüksek Lisans Tezi). Pamukkale Üniversitesi, Denizli.

Akpur, U. (2005). Öğrenilmiş çaresizlik ve kaygı düzeylerinin İngilizce başarı düzeyine etkisi (Yüksek Lisans Tezi). Yıldız Teknik Üniversitesi, İstanbul.

Ann, R. (1983). Techniques in teaching writing. New York: Oxford University Press.

Arıc1, A. F., \& Ungan, S. (2015). Yazılı anlatım el kitabı. Ankara: Pegem Akademi.

Aytan, N., \& Tunçel, H. (2015). Yabancı dil olarak Türkçe yazma kaygısı ölçeğinin geliştirilmesi çalışması. Mustafa Kemal Üniversitesi Sosyal Bilimler Enstitüsü Dergisi, 12(30), 50-62.

Bağ, G. (2013). Lise öğrencilerinin yabancı dil kaygı düzeyleri ile İngilizce dersine yönelik tutumları ve akademik başarıları arasındaki ilişki. Atatürk Üniversitesi Kazım Karabekir Eğitim Fakültesi Dergisi, 27, 127-146.

Bağcı, H. (2011). Yazılı anlatım ve unsurları. In M. Özbay (Ed.), Yazma eğitimi içinde (pp. 85-126). Ankara: 
Pegem Akademi.

Balcı, A. (2020). Yabancı dil olarak Türkçe öğrenen ögrrencilerin yazma kaygılarının araştırılması (Yüksek Lisans Tezi). Çanakkale Onsekiz Mart Üniversitesi, Çanakkale.

Batumlu, D. Z. U. (2006). YTÜ yabancı diller yüksekokulu hazırlı ögrencilerinin yabancı dil kaygılarının İngilizce başarılarına etkisi (Yüksek Lisans Tezi). Yıldız Teknik Üniversitesi, İstanbul.

Can, A. (2014). Spss ile bilimsel araştırma sürecinde nicel veri analizi. Ankara: Pegem Akademi Yayıncılık. https://doi.org/10.14527/9786053644484

Çelebi, S. (2009). Teachers and students' views on anxiety in English classrooms and attitudes towards English (Yüksek Lisans Tezi). Çukurova Üniversitesi, Adana.

Cheng, Y. (2004). A measure of second language writing anxiety: Scale development and preliminary validation. Journal of Second Language Writing, 13(4), 313-335. https://doi.org/10.1016/j.jslw.2004.07.001

Cheng, Y. S. (2002). Factors associated with foreign language writing anxiety. Foreign Language Annals, 35(5), 647-656. https://doi.org/10.1111/j.1944-9720.2002.tb01903.x

Cheng, Y. S., Horwitz, E. K., \& Schallert, D. L. (1999). Language anxiety: Differentiating writing and speaking components. Language Learning, 49, 417-449. https://doi.org/10.1111/0023-8333.00095

Choi, S. (2013). Language anxiety in second language writing: Is it really a stumbling block? Second Language Studies, 31(2), 1-24.

Corbett-Whittier, C., (2004). Writing apprehension in adult college undergraduates: Six case studies (Doctoral Dissertation). University of Kansas, Kansas.

Dalkılıç, N. (2001). An investigation into the role of anxiety in second language learning (Doktora Tezi). Çukurova Üniversitesi, Adana.

Daud, N. M., Daud, N. M., \& Kassim, N. L. A. (2005). Second language writing anxiety: Cause or effect? Malaysian Journal of ELT, 1(1), 1-19.

Ekiz, E. (2017). Bilimsel araştırma yöntemleri. Ankara: Anı Yayıncılık.

Ekmekçi, E. (2018). Exploring Turkish EFL students' writing anxiety. The Reading Matrix: An International Online Journal, 18(1), 158-175.

Faigley, L., Daly, J. A., \& Witte, S. P., (1981). The role of writing apprehension in writing performance and $\begin{array}{lllll}\text { writing } & \text { Jompetence. Journal of Educational Research, } & \text { 75, }\end{array}$ https://doi.org/10.1080/00220671.1981.10885348

Göçer, A. (2007). Türkçe öğretimi. Ankara: Öncü Kitap.

Göçer, A. (2014). The relationship between anxiety and attitude of students learning Turkish as a foreign language and their achievement on target language. Educational Research and Reviews, 9(20), 879-884. https://doi.org/10.5897/err2014.1784

Gülsün, R. (1997). An analysis of the relationship between learners' foreign language classroom anxiety and achievement in learning English as a foreign language in the freshman classes at the University of Gaziantep (Yüksek Lisans Tezi). Gaziantep Üniversitesi, Gaziantep.

Günaydın, Y., \& Arıcı, A. F. (2020). Türkçenin yabancı dil olarak öğretiminde etkileşimli okumanın konuşma becerisine etkisi. EKEV Akademi Dergisi, 24(83), 673-696. https://doi.org/10.17753/Ekev1688

Güneş, F. (2014). Türkçe öğretimi yaklaşımlar ve modeller. Ankara: Pegem Akademi. https://doi.org/10.14527/9786053644927

Ho, M. C. (2016). Exploring writing anxiety and self-efficacy among EFL graduate students in Taiwan. Higher Education Studies, 6(1), 24-39. https://doi.org/10.5539/hes.v6n1p24

Horwitz, E. K., Horwitz, M. B., \& Cope, J. (1986). Foreign language classroom anxiety. Modern Language Journal, 70(2), 125-132. https://doi.org/10.1111/j.1540-4781.1986.tb05256.x

İşcan, A. (2015). Yabancı dil olarak Türkçe öğretiminde yazma kaygısı üzerine bir inceleme (Ürdün Üniversitesi örneği). Dil ve Edebiyat Ĕ̈itimi Dergisi, 14, 135-152.

İşeri, K., \& Ünal, E. (2012) Türkçe öğretmen adaylarının yazma kaygı durumlarının çeşitli değişkenler açısından incelenmesi. Mersin Üniversitesi Ĕ̈itim Fakültesi Dergisi, 8(2), 67-76. 
Jawas, U. (2019). Writing anxiety among Indonesian EFL students: Factors and strategies. International Journal of Instruction, 12(4), 733-746. https://doi.org/10.29333/iji.2019.12447a

Jebreil, N., Azizifar, A., Gowhary, H., \& Jamalinesari, A. (2015). A Study on Writing Anxiety among Iranian EFL Students. International Journal of Applied Linguistics \& English Literature, 4(2), 68-72.

Karadağ, Ö., \& Maden, S. (2014). Yazma Eğitimi: Kuram, uygulama, ölçme ve değerlendirme. In A. Güzel, \& H. Karatay (Eds.), Türkçe Ögrretimi El Kitabı içinde (pp. 265-306). Ankara: Pegem Akademi. https://doi.org/10.14527/9786053645269.11

Karakaya, İ., \& Ülper, H. (2011). Yazma kaygısı ölçeğinin geliştirilmesi ve yazma kaygısının çeşitli değişkenlere göre incelenmesi. Kuram ve Uygulamada Eğitim Bilimleri, 11(2), 691-707.

Karatay, H., \& Aksu, Ö. (2017). 4+1 planlı yazma ve değerlendirme modelinin 8. sınıf öğrencilerinin ev ödevlerini hazırlamaya etkisi. Ana Dili Ĕgitimi Dergisi, 5(2), 313-335. https://doi.org/10.16916/aded.302765

Karateke-Bayat, B. (2018). Yabancı dil olarak Türkçe öğretiminde akran değerlendirmesinin öğrencilerin yazma kaygısına etkisi (Yüksek Lisans Tezi). Nevşehir Hacı Bektaş Veli Üniversitesi, Nevşehir.

Kassem, M. A. M. (2017). Developing business writing skills and reducing writing anxiety of EFL learners through wikis. English Language Teaching, 10(3), 151-163. https://doi.org/10.5539/elt.v10n3p151

Kim, E., \& Ehrmann K. (2013). Reliability of power profiles measured on NIMO TR1504 (Lambda-X) and effects of lens decentration for single vision, bifocal and multifocal contact lenses. Journal of Optometry, 9(2), 126-136. https://doi.org/10.1016/j.optom.2015.10.005

Kırmızı, Ö., \& Kırmızı, G. D. (2015). An investigation of L2 learners' writing self-efficacy, writing anxiety and its causes at higher education in Turkey. International Journal of Higher Education, 4(2), 57-66. https://doi.org/10.5430/ijhe.v4n2p57

Köse,E. (2017). Bilimsel araştırma modelleri. In R. Y. Kıncal (Ed.), Bilimsel araştırma yöntemleri içinde (pp. 99-122). Ankara: Nobel Yayincilik.

Lin, G. H., \& Ho, M. M. (2009). An exploration into foreign language writing anxiety from Taiwanese University students' perspectives. Retrieved from https://files.eric.ed.gov/fulltext/ED506178.pdf

Liu, M., \& Ni, H. (2015). Chinese University EFL learners' foreign language writing anxiety: Pattern, effect and causes. English Language Teaching, 3, 46-58. https://doi.org/10.5539/elt.v8n3p46

Maden, S., Dinçel, Ö., \& Maden, A. (2015). Türkçeyi Yabancı Dil Olarak Öğrenenlerin Yazma Kaygıları. Uluslararası Türkçe Edebiyat Kültür Eğitim Dergisi, 4(2), 748-769. https://doi.org/10.7884/teke.488

Martinez, T., Kock, N., \& Cass, J. (2011). Pain and pleasure in short essay writing: Factors predicting university students' writing anxiety and writing self-efficaty. Journal of Adolescent \& Adult Literacy, 54(5), 351-360. https://doi.org/10.1598/jaal.54.5.5

Özbay, M. (2006). Türkçe özel ögretim yöntemleri. Ankara: Öncü Yayınc1lık.

Özbay, M., \& Zorbaz K. Z. (2011). Daly-Miler'ın yazma kaygısı ölçeğinin Türkçeye uyarlanması. Mustafa Kemal Üniversitesi Sosyal Bilimler Enstitüsü Dergisi, 8(16), 33-48.

Öztürk, H., \& Çeçen S. (2007). The effects of portfolio keeping on writing anxiety of efl students. Journal of Language and Linguistic Studies, 3(2), 218-236.

Rezaei, M., \& Jafarib, M. (2014). Investigating the Levels, Types, and Causes of Writing Anxiety among Iranian EFL Students: A Mixed Method Design. International Conference on Current Trends in ELT. Procedia Social and Behavioral Sciences, 98, 1545-1554. https://doi.org/10.1016/j.sbspro.2014.03.577

Şen, Ü., \& Boylu, E. (2017). Türkçeyi yabancı dil olarak öğrenenlere yönelik yazma kaygısı ölçeğinin geliştirilmesi. Uluslararası Türkçe Edebiyat Kültür Eğitim Dergisi, 6(2), 1122-1132. https://doi.org/10.7884/teke.3886

Sever, S. (2004). Türkçe öğretimi ve tam öğrenme. Ankara: Anı Yayıncılık.

Shang, H. (2013). Factors associated with English as a foreign language university students writing anxiety. International Journal of English Language Teaching, 1, 1-12.

Sönmez, V., \& Alacapınar, F. G. (2013). Örneklendirilmiş bilimsel araştırma yöntemleri. Ankara: Anı Yayıncılık.

Taşdemir, O. (2017). Yabancılara Türkçe öğretiminde özel yazmanın yazma kaygısı ve yazma eğilimine etkisinin 
incelenmesi (Yüksek Lisans Tezi). Dokuz Eylül Üniversitesi, İzmir.

Tayşi, E. K. (2018). Yabancı dil olarak Türkçe yazma kaygısı ölçeğinin geliştirilmesi: Geçerlik ve güvenirlik çalışması. Türkiye Sosyal Araştırmalar Dergisi, 22(4), 1033-1050.

Tiryaki, E. N. (2012). Üniversite öğrencilerinin yazma kaygısının çeşitli değişkenler açısından belirlenmesi. Dil ve Edebiyat Eğitimi Dergisi, 1(1), 14-21.

Türk Dil Kurumu (TDK) (2017). Büyük Türkçe sözlük. Ankara: TDK Yayınları.

Ülper, H., \& Çeliktürk Sezgin, Z. (2019). Eğitim fakültesi öğrencilerinin yazma alışkanlığı profillerinin belirlenmesi. Mehmet Akif Ersoy Üniversitesi Eğitim Fakültesi Dergisi, 49, 166-170.

Yan, J. X., \& Horwitz, E. K. (2008). Learners' perceptions of how anxiety interacts with personal and instructional factors to influence their achievement in English: A qualitative analysis of efl learners in China. .(1), 151-183. https://doi.org/10.1111/j.1467-9922.2007.00437.x

Zhang, H. (2011). A study on ESL writing anxiety among Chinese English majors: Causes, effects and coping strategies for ESL writing anxiety. Kristianstad University.

Zorbaz, K. Z. (2011). Yazma kaygısı ve yazma kaygısının ölçülmesi. e-Journal of New World Sciences Academy, 6(3), 2271-2280.

\section{Copyrights}

Copyright for this article is retained by the author(s), with first publication rights granted to the journal.

This is an open-access article distributed under the terms and conditions of the Creative Commons Attribution license (http://creativecommons.org/licenses/by/4.0/). 